\title{
単分子膜リソグラフィと選択無電解めっきによる 金微細構造の作製
}

杉村博之*，判治貴之*，牛山和哉**，高井 治*

\section{Application of Self-Assembled Monolayer Lithography : Fabrication of Gold Microstructures through Area-Selective Electroless Plating}

Hiroyuki SUGIMURA*, Takayuki HANJI*, Kazuya USHIYAMA** and Osamu TAKAI*

Key Words : Organosilane Self-Assembled Monolayer, Photolithography, Electroless Gold Plating

\section{1. 緒 言}

酸化物表面の水酸基を有機シラン化合物分子で化学修 飾すると, 膜厚数 $\mathrm{nm}$ 以下の自己組織化単分子膜 (SAM, Self-Assembled Monolayer)が形成される ${ }^{1)} 。$ 機械的強度および化学的耐久性が高く, フォトリソグラ フィ用レジスト膜としての応用が期待されている ${ }^{2), 3)}$ 本論文では, 有機シラン単分子膜のフッ酸に対する化学 耐久性と, 単分子膜マスクを用いる選択無電解めっきに よる金微細構造の作製について報告する。

\section{2. 実験}

図 1 に，金微細構造作製のためのプロセスを示す。シ リコン自然酸化膜表面に, オクタデシルトリメトキシシ ラン (n-octadecyltrimethoxysilane, $\mathrm{n}-\mathrm{C}_{18} \mathrm{H}_{37} \mathrm{Si}$ $\left(\mathrm{OCH}_{3}\right)_{3}$, 東京化成工業) から, 気相合成法によって有 機シラン単分子膜を被覆した ${ }^{4)}$ 。偏光解析法によって測 定した膜厚は $1.9 \pm 0.1 \mathrm{~nm}$ であった。試料表面にフォ トマスクを密着させ, マスク越しに波長 $172 \mathrm{~nm}$ の Xe 2 エキシマランプ光(ウシオ電機製, UEM 20-172) を照 射し, 単分子膜をパターニングした(図 1 a)。フォトマ スク通過後の膜面でのエキシマ光強度は, 約 $6.5 \mathrm{~mW} /$ $\mathrm{cm}^{2}$ であった。エキシマ光照射された単分子膜は, C-C 結合が切断され分解・除去される。照射時間 $400 \mathrm{~s}$ (照射 光量 $\left.2.6 \mathrm{~J} / \mathrm{cm}^{2}\right)$ で, ほほ完全に単分子膜を除去するこ とができる(図 1 b)。

光パターニングした試料をフッ酸 $(\mathrm{HF})$ でエッチング

* 名古屋大学大学院 工学研究科（T464-8603 愛知県名古屋 市千種区不老町)

Graduate School of Eng., Nagoya Univ. (Furo-cho, Chikusa-ku, Nagoya-shi, Aichi 464-8603)

**名古屋大学大学院 工学研究科 ( T464-8603 愛知県名古屋 市千種区不老町) [現・三井金属鉱業(㑣]

Graduate School of Eng., Nagoya Univ. (Furo-cho, Chikusa-ku, Nagoya-shi, Aichi 464-8603) [Present: Mitsui Mining \& Smelting Co., Ltd.]
し(図 1 c), さらに, 市販の置換型無電解めっき液(高 純度化学, K-24 S) で処理した(図 1 d)。

\section{3. 結果および考察}

単分子膜がエッチングマスクとして使用可能であるか どうかを確かめるため, 光照射をしていない単分子の HF 耐久性を調べた。

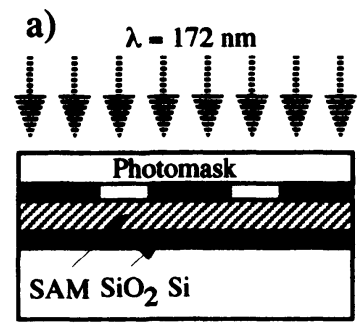

b)

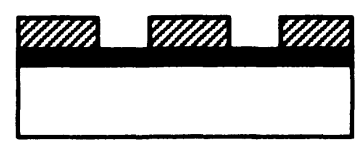

c)

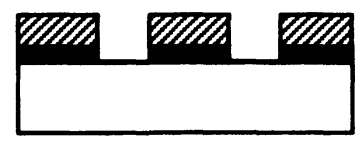

d)

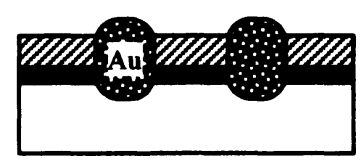

Fig. 1 Process chart for fabrication of microstructures on Si.

a) Photopatterning in vacuum $(<10 \mathrm{~Pa})$, b) Patterned SAM, c) $\mathrm{HF}$ ething ( $1 \%, 1 \mathrm{~min})$, and d) $\mathrm{Au}$ electroless plating $\left(70^{\circ} \mathrm{C}, 4 \mathrm{~min}\right)$. 


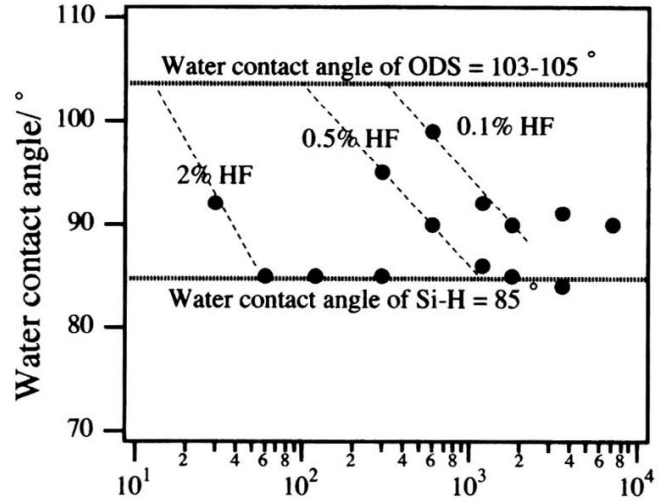

Etching time / sec

Fig. $2 \mathrm{HF}$ resistivity of the organosilane self-assembled monolayer.

図 2 は, 濃度 2.0,0.5,0.1 wt.\%の各 $\mathrm{HF}$ 水溶液に 浸漬した単分子膜被覆基板の水滴接触角の変化を示して いる。HF 浸漬によって接触角は徐々に減少し, 約 85 度で一定となった。この 85 度という接触角は希薄 HF 中でシリコン基板を処理した時に形成される水素終端化 シリコン表面の水滴接触角にほほ等しい。HF浸漬に よって単分子膜とシリコン基板の中間にある自然酸化膜 がエッチングされ，単分子膜がはく離したものと考えら れる。図 2 より単分子膜の HF 耐久時間を見積もると, 濃度 $2.0 ， 0.5 ， 0.1 \%$ で，それぞれ，約 $15 ， 100 ， 3000$ $\mathrm{s}$ となる。同 $\mathrm{HF}$ 濃度でのシリコン酸化膜のエッチング 速度は，それぞれ，0.4，0.06，0.008 nm/sであった。 有機シラン単分子膜は, 膜厚約 $2 \mathrm{~nm}$ のシリコン自然酸 化膜の HF エッチングマスクとして，十分な耐久性が ある。

めつき処理後の試料表面の光学顕微鏡写真を図 3 に示 す。金が析出している領域は反射率が高いため明るく見 える。光照射領域 (幅約 $2 \mu \mathrm{m} \times$ 長さ約 $10 \mu \mathrm{m}$ )に, 金が 選択的に析出している。単分子膜が光除去された領域 (図 1 b)のシリコン酸化膜を, HFにより除去し(図 1 c), さらに, 露出した下地シリコンと金錯イオンとの 置換反応によって，金が析出した(図 $1 \mathrm{~d})$ 。逆に，光照

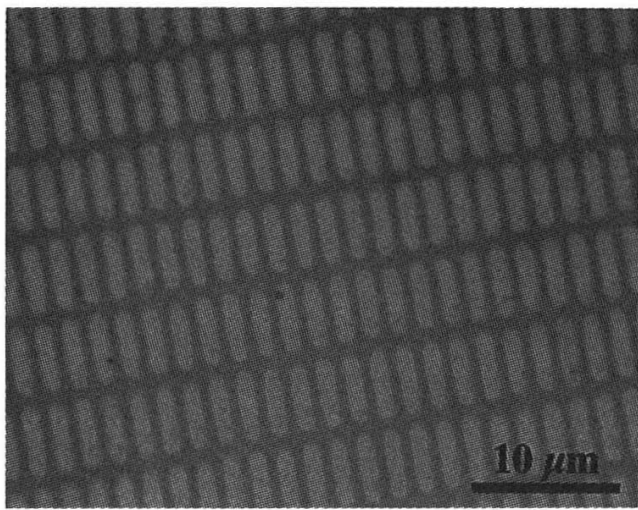

Fig. 3 Optical micrograph of Au microstructures.

射されていない領域では, 単分子膜によって, エッチン グおよびめっき反応が完全にマスクされている。

\section{4. 結言}

有機シラン分子の自己組織化単分子膜をレジスト膜と する, 真空紫外光リソグラフィ・プロセスを開発した。 これまでに, 使用したフォトマスク・パターンの最小サ イズである $2 \mu \mathrm{m}$ までの微細構造を転写することに成功 している。また, 光パターニングした単分子膜をテンプ レートとし, 選択無電解めっきによって金マイクロパ ターンを作製することができた。

本研究は, 文部省科学研究費補助金・特定領域研究(A) 「構造規制機能界面の構築と電極反応」(領域番号 282) により助成を受けて行われた。

(Received September 29, 1999 ; Accepted November 2, 1999)

\section{文献}

1) J. Sagiv ; J. Am. Chem. Soc., 102, 92 (1980)

2 ) C. S. Dulcey, J. H. Georger Jr., V. Krauthamer, D. A. Stenger, T. L. Fare and J. M. Calvert ; Science, 252, 551 (1991)

3 ) H. Sugimura, and N. Nakagiri ; Appl. Phys. A, 66, S 427 (1998)

4) H. Sugimura and N. Nakagiri ; J. Photopolym. Sci. Technol., 10, 661 (1997) 